\title{
THE ANOMALY OF GOOD-LOOKING : THE RELATIONSHIP BETWEEN SPIRITUALITY AND EXTREMISM ON HADITH AND SOCIAL RELIGIOUS PERSPECTIVE
}

\author{
Zulfahmi Alwi \\ Universitas Islam Negeri Alauddin Makassar \\ zulfahmi.alwi@uin-alauddin.ac.id
}

\author{
Akbar \\ Institut Agama Islam Negeri Kendari \\ akbar@iainkendari.ac.id
}

\author{
Amin Hady \\ The Founder and Chairman of The Foundation of Islamic Studies and \\ Information (FISI) Sydney, Australia \\ ahady@arts.usyd.edu.au \\ Abdul Muiz Amir \\ Institut Agama Islam Negeri Kendari \\ abdulmuiz@iainkendari.ac.id \\ Jawiah Dakir \\ Pertubuhan Legasi Tun Abdullah Ahmad Badawi, Malaysia \\ jawiahd53@gmail.com \\ Latifah Abdul Majid \\ Universiti Kebangsaan Malaysia, Malaysia \\ umilm@ukm.edu.my
}

\begin{abstract}
The stereotype of Islam as an extremist religion is often associated with adherence in a good-looking character to the practices of ritual piety. This study aims to discuss the Hadith that allegedly refers to the presence of good-looking phenomenon from the prophetic period. The study uses a descriptive qualitative research
\end{abstract}


design which relates to the basis of critical analysis through an interdisciplinary approach combining isnād-cum-matn and socio-religious phenomenology. The results indicate that the Hadith good-looking is șahịh (authentic) based on the review of its sanad transmission and examination on its matn. The goodlooking trait is attributable to the emptiness of morality in the practice of Islamic spirituality. This vacuity is induced by religious insights focused solely on theological and normative viewpoints. The solution is to spread moral teaching and moderate religious values proactively through different methods and techniques, such as virtual proselytizing in social media.

Keywords: Extremism, Good-looking, Hadith, Social Religious

\section{A. Introduction}

Muslims who adhere to the ritual practices of their religious teachings are often portrayed to be associated with radicalism, intolerance, extremism, and even terrorism. This occurrence coincides with the controversy emerged from the statement of the Minister of Religious Affairs of the Republic of Indonesia (term of office 2019-2020) during a national seminar in Jakarta, Indonesia. He believed that religious radicalism often arose from Muslim groups that appeared pious and rigorous in their worship routines but having restrictive social relationships in contrast. At that time, he described it as good-looking (Asih, 2020). The claim appears to imply a schism between ritual piety and social piety. Although it is undeniable that some religious figures use the appearance of their ritual piety to attain political and economic advantage (Amir, 2019). Conceptually, someone who practices Islamic teachings and is dutiful in forming ritual worship will be protected from behaviors and attitudes that are considered to be vile and evil, as “...inna al-ṣalāh tanhā 'an al-fakhsyā' wa al- 
munkar..." ("Indeed prayer prevents heinous and evil acts") (Q. 29:45).

On the one hand, a closer examination of the sacred texts of Islamic teachings reveals Hadith narrations that explicitly encourage Muslims to dress exclusively in the manner that characterizes the Prophet's "sunnah", as well as prohibitions against performing tasyabbuh or resembling the appearance of other religions (Sulaemang et al., 2019). For example, a Hadith urges Muslims to preserve their beards and forbids the wearing of isbāl trousers (pants must not go beyond the ankles). On the other hand, Hadith narrations show that such appearances are associated with extremist Muslims. This abnormality has prompted the research's academic curiosity. Thus, it is critical to look into it using three primary questions: (1) How does the narration of the Hadith explain the relationship between ritual piety and violent practices in religion? (2) Why do the practices of religious violence tend to emerge from people who are obedient in practicing goodlooking religious rituals?; (3) How to overcome the dangers that may arise from a good-looking way of religion? Finding answers to the above questions is important to avoid the wishful thinking that every devout Muslim who performs ritual acts of worship righteously is a part of terrorist groups.

A significant number of related studies on the subject have been carried out by concerned scholars including, Achilov and Sen (2017); Amir (2019); Ansor (2016); Rijal (2020); Slama and Barendregt (2018); Syam et al. (2020); and Wahib (2017). Specifically, their study focused on analyzing the relationship between ritual piety and identity politics as a variant of religious features between moderation and radicalism, focusing on Muslims in Indonesia. Their findings indicate that the basis of the distinction between moderation 
and radicalism is determined by the way they understand religious texts. Moderate understanding is formed by or the result of a broader understanding of religious texts. Inversely, the radicalist's view was generated by their limited textual understanding of Islamic literature, specifically text of Qur'an and Hadith (Duderija, 2007; Wiktorowicz, 2005). By limiting their study on the textual meaning of these Islamic literature, they failed to understand the broader context between extremism and violent behavior. Without having a proper understanding of text messages, the positive meaning of the Prophet's message can be diverted easily. Other research related to hermeneutic analysis studies of al-Qur'an and Hadith on the act of violence in religion has been conducted by Afsaruddin (2008; 2009); Faisal (2018); Sanjev Kumar (2018); and Tabti (2019). They reveal that the act of religious violence is vulnerable to being influenced by the method of interpreting sacred texts they use. That is what triggers the emergence of Islamophobia which claims that Islamic teachings are synonymous with violence. Further tracing on these studies has revealed that there is minimal enough effort made on understanding the connection between the meaning of the Hadith reports on ritual piety and its implications on the practice of violence.

This research argues that the Hadith on the relationship between ritual act based on righteousness and religious violence is sahịh (authentic) based on isnād-cum-matn analysis. However, the context of the Hadith's history shows the historical fact that the relationship between the two is strange. On one hand, people who are obedient to ritual worship obey the religious teachings manifested in the revealed texts. On the other hand, this obedience still could trigger them to commit violence in the name of religion. This 
tendency arises when a person is not equipped with enough sense of morality through broad insights in carrying out their religious teachings, making them strongly feel that they are on the absolute and the only true path.

\section{B. Religiosity, Spirituality, and Morality in Religious Terminology}

The Muslim clergy frequently uses exclusive symbols in a definite pattern of religious lifestyle and identity to define their group. Consequently, some Muslim communities' dogmas about the way how to dress, speak, and act are among these emblems. First, they learn how to dress in the "sunnah" style, such as wearing anti-Islam pants, growing a beard, marking dark on the brow, wearing a cap, and so on. Second, they interact with the people around them using everyday conversations that they adapt from a variety of Arabic vocabularies, such as anā (me), antum (you), akhī (brother), and others. Third, they are more concerned with memorizing the Qur'an than analyzing its meaning. The good-looking term stated by the Minister of Religious Affairs appears to have replied to this phenomenon. He revealed that individuals who tend to show religious appearance, master Arabic, memorize the Qur'an (hāfiz), or what he calls good-looking can act as an agent of radicalism that needs to be monitored. This statement received a response accusing him of being an individual who was not competent to justify his statement (Asih, 2020).

It has to be admitted that religion is just one part of social identity, a concept that remains difficult to define universally. This is especially the case when we try to comprehend it within the framework of multiple religions of the world. Kimball (2002) mentions this concern in his definition of religion. He argued that when religious communities were 
asked about the meaning of the term of religion, they tended to answer according to the religion they profess (Kimball, 2002). Larsen and Rinkel (2016) made a similar argument in their study, which found that between 79.4 and $97.9 \%$ of social workers describe religion in their way. It is a huge question that still raises issues in the study of religious dialogue. As a response, Kimball (2002) emphasizes that the concept of truth over religions will be decreased unless the differences factors between religions as a differentiating benchmark are open for discussion. Also, it will be very challenging to find a unification on the diversity of religions in the world. In addition, he also argues that there was a tendency for the definition of religion to be limited to ritual practices, worship, and transcendental obedience, which narrowed its scope down even more (Kimball, 2002). Thus, it is not enough to see spirituality only as one religious entity isolated from other entities representing religious articulation.

It seems that Koenig et al., (2000) definition of religion in his book "Handbook of Religion and Health" is more appropriate to respond to Kimball's anxiety on the subject. Koenig, et al. defined religion as a system of beliefs, practices, rituals, and symbols organized and designed to facilitate a close relationship with two elements, God as sacred or transcendent. The relationship between fellow beings to coexist with each other social community (Koenig et al., 2000). This definition gives birth to two behaviors in religion, religiosity and spirituality. Suppose religiosity appears to be more general by simultaneously including individual and collective behavior. In that case, spirituality is more likely to lead to individual interests in performing only religious practices. Spirituality is a path taken by a person to understand the meaning of life through his relationship with 
transcendental God, which is also known as ritual piety (Hogg et al., 2010; Osman-Gani et al., 2013). Thus, it cannot reflect religious terminology as a whole as spirituality or ritual piety represents only one fragment of the definition of religion.

One of the fragments of religion that are often forgotten is morality which functions as an adhesive aspect between religiosity and spirituality (Baumsteiger et al., 2013). Morality is used as a simple concept to measure indicators of the values contained in a person's religious attitude, both in individual and communal spheres. Morality could give birth to values of truth that shape the character of spirituality in a servant's relationship with God. Likewise, morality also forms the values of social solidarity or brotherhood in an attitude of religiosity that connects people (Kimball, 2002). Therefore, without values of morality that link the values of religiosity and spirituality, violence could become part of the truth claimed against a particular religion.

\section{Characteristics of Violence in Religion}

Before discussing the factors thatunderlie the emergence of violence in religion, it is important to look at the motivation or psychological orientation underlying people's tendencies to posit religion as a social identity. The study conducted by Henningsgaard and Arnau (2008) shows at least two major groups on this issue, namely, "extrinsic" and "intrinsic". In its simplest terms, intrinsic is a person's tendency to position religion as the goal of life and as the center of his identity (way of life). While extrinsic is the tendency for a person to position religion as a hegemonic tool to achieve the goals of various interests, be they social, theological, political, economic, or cultural (Henningsgaard \& Arnau, 2008). This extrinsic attitude can have the opportunity to cause violence in religion 
by certain religious groups, which are often associated using the term violent extremism (Hogg et al., 2010).

However, violent extremism is often associated with widespread religious violence against certain religious groups. Wibisono et al. revealed that the term has failed to capture different interpretations, beliefs, and attitudes when defining the identity of violence in religion. Furthermore, they also emphasized multidimensional religious extremism that includes theological, ritual, social, and political dimensions of faith based on the diversity of religious groups. Therefore, in some cases, violence in religion does not have to be generalistic because there may be religious groups that are extreme in some dimensions but moderate in other dimensions, for example, radical in ritual but moderate in politics (Wibisono et al., 2019). Religious violence or extremism is also often associated with the ideology of fundamentalism. The term fundamentalism in the literature of religious psychology is articulated as a religious ideology that understands literal revelation texts to be used to claim a single truth, feel part of the religious elite, and view secular or other religious groups as threats from outside (Cohen \& Johnson, 2017).

The results of the preliminary investigation revealed historical facts that Hadith reports complied with Minister of Religion of the Republic of Indonesia statement. It can be seen in the following Hadith extracts;

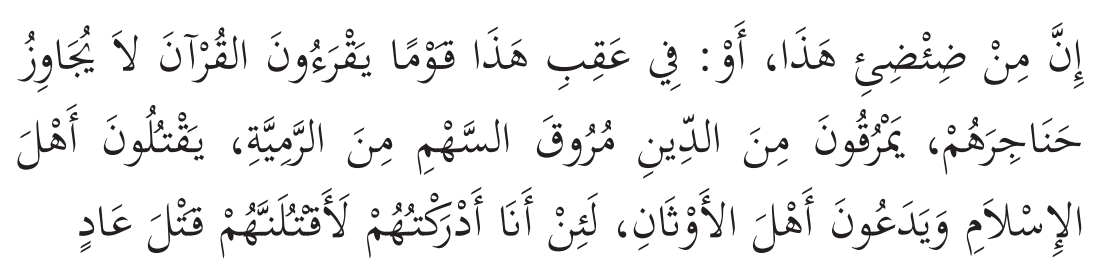


Meaning: the Prophet said, "Among the offspring of this man will be some who will recite the Qursan but the Qursan will not reach beyond their throats (i.e., they will recite like parrots and will not understand it nor act on it), and they will renegade from the religion as an arrow goes through the gamess body. They will kill the Muslims but will not disturb the idolaters. If I should live up to their time> I will kill them as the people of «Ad were killed (i.e., I will kill all of them)» (https://sunnah. com/bukhari:3344).

A number of scholars argue that the Hadith narrative describes the prophecy of the Prophet regarding the characteristics of groups of Muslims who are devout to ritual worship but who are prone to violence in the name of religion. According to Muhammad b. 'Abdullāh al-Syaukānī, the Hadith narrations describe a group of Muslims who only present a symbolic appearance of piety but have very poor religious qualifications. They are simply concerned with the appearance of ritual piety and are unconcerned with social morality. These are the folks who are most at risk of having their religious piety used to justify violence in the name of religion (Al-Syaukānī, 1993, Vol. 7, p. 194).

The phenomenon of religious violence has long been a global concern, including Indonesia. When governments prepare counter-terrorism policies, they predominantly focus on reactive actions that are repressively oriented, such as military action and surveillance measures that are responsive to radicalized individuals or groups. Such a step is considered inaccurate, and instead of eliminating the notion of religious violence, it is precisely considered that this is increasingly convincing for certain individuals or religious groups to feel they are in the oppressed truth (Ghosh et al., 2017). Thus, 
it is difficult to solve the problem without making a radical identification by investigating the characteristics of religious violence they profess. Kimball (2002) mentions five main indicators that can be identified as part of the characteristics of religious violence. First, absolute truth clime, a religious attitude that tends to claim single truth and exclude other truths. Second, blind obedience, culturing an ideology against certain religious practices, and negatively marginalizing others. Third, establishing the ideal time, determining a certain time in the context of realizing the revival movement as a form of repressive resistance. Fourth, justifies any means, or does everything possible to realize a truth that they consider absolute. Fifth, declaring holy war or warfare as a solution to destroy all forms of evil in the world (Kimball, 2002). These five indicators are used to identify the relationship between ritual piety and aspects of religious violence embodied in the history of the good-looking Hadith.

\section{Method}

This study used a descriptive qualitative design based on the critical analysis paradigm and socio-religious phenomenology. The database of this research uses literature review or literature research that aims to trace information from the Hadith history about the relationship between ritual piety and the violence practice in religion. The primary data source used is a collection of pre-canonical, canonical, and post-canonical Hadith books. The canonical Hadith literature is al-Kutub al-Tis'ah (nine standard books on Sunni tradition, they are: Șahịh al-Bukārī, Șahīh Muslim, Sunan Abū Dāud, Sunan at-Tumūżì, Sunan Ibn Mājah, Sunan an-Nasā'ī, Muwațtā' Imām Mālik, and Musnad Ahmad bin Hanbal). Pre-canonical is literature that appeared before, such as the book Mușannaf Ibn 
Abī Syaibah and the book Mușannaf 'Abd al-Razzāq al-San'ānī. Post-canonical sources are Hadith literature that appeared after canonical literature or what is meant in this study is the book Al-Mustadrak 'alā al-Ṣahịhain. The limitation on the 12 pieces of literature was carried out because the books represented the Hadith literature which methodologically fulfilled the general standards of Hadith critics scholars. The secondary sources used are the literature jarh wa ta'dil (scholar's explanation of the status of isnād/chain of the transmitter), syarah Hadith literature (scholar's description of the Hadith), and other literature related to this research.

Data collection was carried out using observation and documentation techniques. The observation technique is carried out by tracing primary data or the Hadith data through the help of two digital book applications, namely, Al-Maktabah al-Syāmilah version 3.64 and Jawāmī 'al-Kalīm version 4.5. Both applications were chosen because they were considered effective and efficient in tracing the Hadith text in the primary literature. However, the application is only used for data exploration, but citing literature sources still refers to the original source. The Hadiths collected are then classified thematically to be documented in tabulated format to facilitate investigations at the data analysis level.

After the primary data is classified into tabulated form, then the data is analyzed using Motzki's (2005) Isnād-cum-Matn Analysis approach, both at the isnād transmission line analysis level or the calendar. At the same time, the matn analysis is projected to trace the originals of the Hadith text. It was done to ensure that the Hadith studied was really at the șahịh (authentic) one. Furthermore, the characteristics of religious violence found in the Hadith are discussed using a hermeneutic-philosophical approach and dialogue with the concepts of religious, social 
phenomenology, particularly the results of Kimball's mapping of the various characteristics of violence. The findings from this discussion are further examined through discussions with various previous studies to ensure a discursive aspect. The final step after conducting the discussion is to conclude the theoretical claims obtained in this study.

\section{E. Good-Looking Articulation in the Hadith Review}

The study of authenticity is a crucial part of the study of Hadith. It distinguishes it from the Qur'anic studies because the Qur'an transmission has been agreed upon and believed by Muslims to be the text of the revelation transmitted communally (mutawātir). That is why the status of Hadith narration is not entirely claimed to have the status of șahịh (really can be relied on to the Messenger of Allah or the early generation of Islam) because the majority of Hadiths are narrated in a limited manner ( $\bar{a} h \bar{a} \bar{d})$. Likewise, in the narration of Hadith, some are narrated lafżì (uniform in structure), and some are maknawī (different in structure, but substantially the same). Therefore, before analyzing the meaning of the Hadith content, it is important to know the transmission of the narrative. It is done by analyzing the isnād (dating) to prove that the Hadiths studied were transmitted validly and authentically from the Prophet or the early generation of Islam in the $7^{\text {th }}$ century of Hijriah.

\section{Isnād Analysis}

The search results using the keyword "yaqra'ūna al-Qur'āna lā yujāwizu" showed that there were 65 narrations recorded in 12 books, except in the book $A l$ Muwatta Mālik. Of the 65 narrations found, there are six 
classifications of Hadith versions, namely, 1) narrations with a standard version using the clause "yaqraūna alQur'āna lā yujāwiżu hanājirahum" ("some who will recite the Qur'an but the Qur'an will not reach beyond their throats") and "yamruqūna min al-dìn kamā yamruq alsahm min al-ramiyyah" ("they will renegade from the religion as an arrow goes through the game's body"); 2) a history that begins with a question about al-Harūriyyah; 3) history as a background of the protest case committed by Żulkhuwaișirah; 4) narration which begins with the story of distributing Hunain's spoils of war in Ji'rānah; 5) the narration which began with 'Alī's feud with Khawārij in Nahrawān; and 6) the history against which the distribution of gold was sent by 'Alī from Yemen. However, the researcher chose to focus on the latest version. This version found as many as 11 historical paths that have identical text.

The choice of this version is because it is found in the phrase, which explicitly contains violent connotations. In addition, this version also has a detailed historical background (wurūd) and is included in the majority of authoritative Hadith books. One of the narrations chosen to be presented as the primary text for further explanation is the Hadith listed in the book Saḥịh al-Bukhārī with Hadith number 3344 as follows:

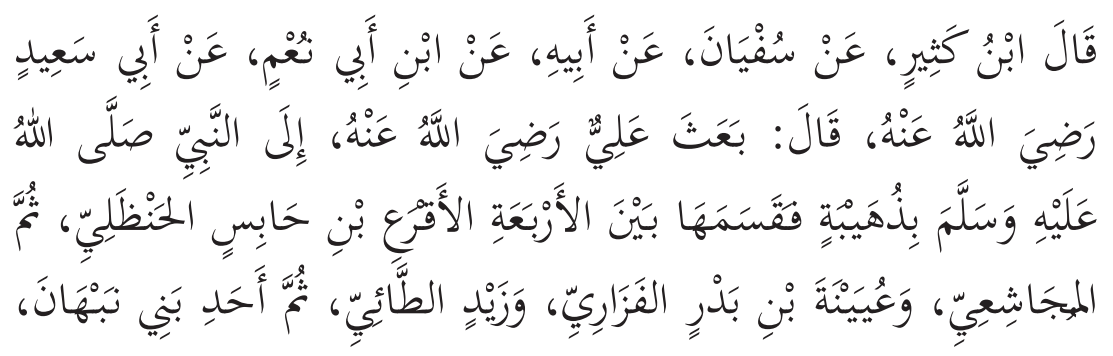




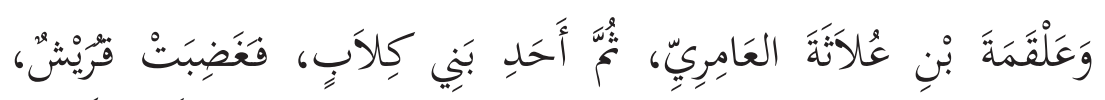

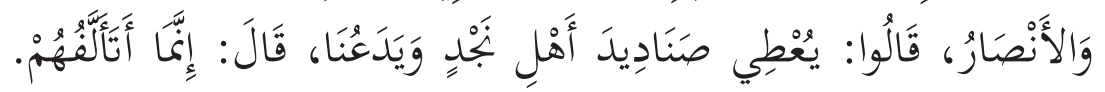

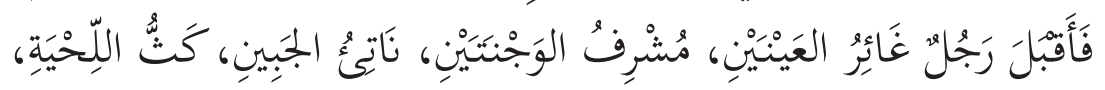

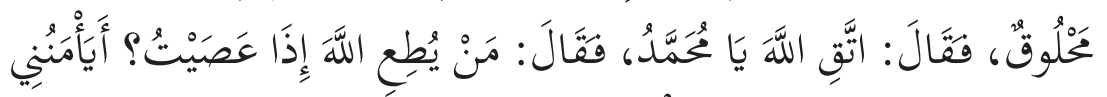

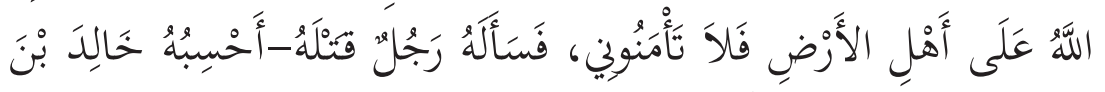

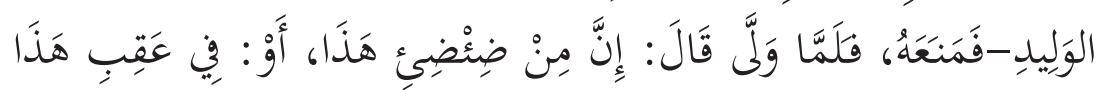

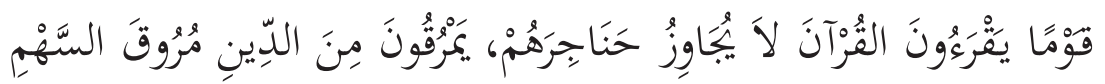

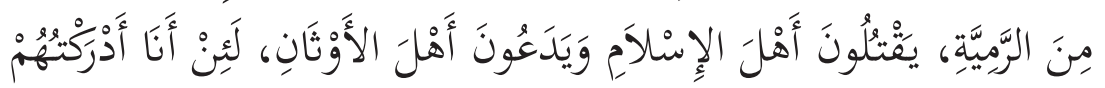

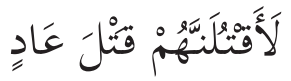

Meaning: Narrated Abu Sa'îd: 'Ali sent a piece of gold to the Prophet (能能) who distributed it among four persons: Al-Aqra> bin H'Abis Al-Hanzali from the tribe of Mujashi, «Uyaina bin Badr Al-Fazari, Zaid atTa>i who belonged to (the tribe of) Bani Nahban, and ¿Alqama bin Ulatha Al-'Amir who belonged to (the tribe of) Bani Kilab. So, the Quraish and the Ansar became angry and said, «He (i.e., the Prophet) gives the chief of Najd and does not give us.» The Prophet

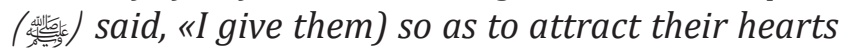
(to Islam).» Then a man with sunken eyes, prominent checks, a raised forehead, a thick beard and a shaven

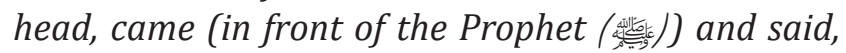
«Be afraid of Allah, O Muhammad!» The Prophet

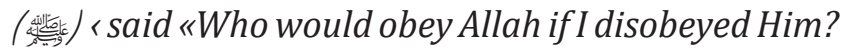
(Is it fair that) Allah has trusted all the people of the earth to me while, you do not trust me?» Somebody who, I think was Khalid bin Al-Walid, requested the Prophet (稢) to let him chop that man's head off, but he prevented him. When the man left, the Prophet (然然) said, "Among the off-spring of this man will be some who will recite the Qursan but the Qursan will not reach beyond their throats (i.e., they will recite like parrots and will not understand it nor act on it), 
and they will renegade from the religion as an arrow goes through the gamess body. They will kill the Muslims but will not disturb the idolaters. If I should live up to their times I will kill them as the people of 〈Ad were killed (i.e., I will kill all of them)» (https:// sunnah.com/bukhari:3344).

The text of this Hadith tells that one time the Prophet (PBUH) distributed gold to a certain group sent by 'Alī bin Abī Tâalib, but the portion of the distribution was protested by people from among the Quraish and Ansar tribes. One of those who protested and accused Rasulullah of being unfair claimed that Rasulullah did not have devotion to Allah. Rasulullah immediately refuted this accusation by stating, "man yuți'illāh iżā 'așaitu, aya'manūniy Allāhu 'alā ahl al-arḍi fa lā ta'manūnī" (Who can obey Allah if I disobey Him, is it proper for Allah to trust me for the inhabitants of the earth when you do not believe in me?). Responding to this condition, Khalīd bin Walid, also present at the event, asked the Prophet for permission to kill the young man, even though the Prophet later forbade it. After that person passed, the Messenger of Allah then revealed the characteristics of certain groups that would emerge from that person's descendants. The Prophet conveyed these criteria in a metaphorical expression which states that

\footnotetext{
«...Among the off-spring of this man will be some who will recite the Qur>an but the Qur>an will not reach beyond their throats, and they will renegade from the religion as an arrow goes through the gamess body. They will kill the Muslims but will not disturb the idolaters. If I should live up to their time> I will kill them as the people of «Ad were killed (https://sunnah.com/bukhari:3344)
} 
Furthermore, to make it easier to understand the transmission lines and takhrij (sources of history in the Hadith literature) of the 11 narrations, they are illustrated in the form of an isnād transmission scheme as shown in figure 1.

Figure 1 shows the narration of the Hadith, which consists of 11 transmission lines, that leads to the exact source of the Sahābah (Companions), namely Abū Sa'îd al-Khudrī (d. 63/682), as well as one Täbi'în (the next generation of companions) source, namely 'Abd al- Raḥmān bin Abī Nu'm (d. 100/718). He was a middle generation Tābi'în (țabaqah al-wusțā) from Kufah who had the șadūq qualification. The students are Sa'îd bin Masrūq (d.126/744) and 'Umārah bin al-Qa'qā' (d. 144/761) who are also both Kufic residents who lived during the junior generation of Tābi'în and had siqah qualifications. Both of them convey history to different students. Sa'īd bin Masrūq conveyed to two of his students, namely Sufyān al-Śaurī (d. 161/777) a narrator with the qualifications of siqah hāfiz and Salām bin Salīm (d. 179/795) who also had the siqah mutqin qualification. Meanwhile, the path of 'Umārah bin al-Qa'qā' transmits the history to two of his students, namely 'Abd alWāhị bin Ziyād (d. 176/792) who qualifies as siqah, and Muhammad bin Fuḍail (d. 295/907) who qualifies as șadūq. The narrative of Sa'īd bin Masrūq is recorded in six works of literature; namely, Al-Musannaf by 'Abd al-Razzāq al-San'ānī (d. 211/826), Musnad Aḥmad by Ahmad bin Hanbal (d. 241/855), Saḥịh Bukhārī by al-Bukhārī (d. 256/870), Șạ̣ịh Muslim by Muslim bin al-Ḥajjāj (d. 261/874), Sunan Abū Dāwud by Abū Dāwud (d. 275/888), and Sunan al-Nasā'̄ by al-Nasā'ī (d. 303/915). While, the narrative of 'Umārah bin al-Qa'qā' is recorded in the literature of Musnad Ahmad, Șaḥị̣ Bukhārī, and Ṣaḥịh Muslim. 


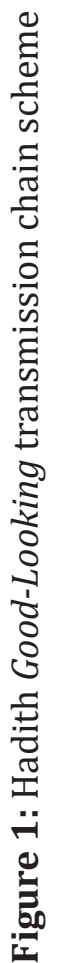

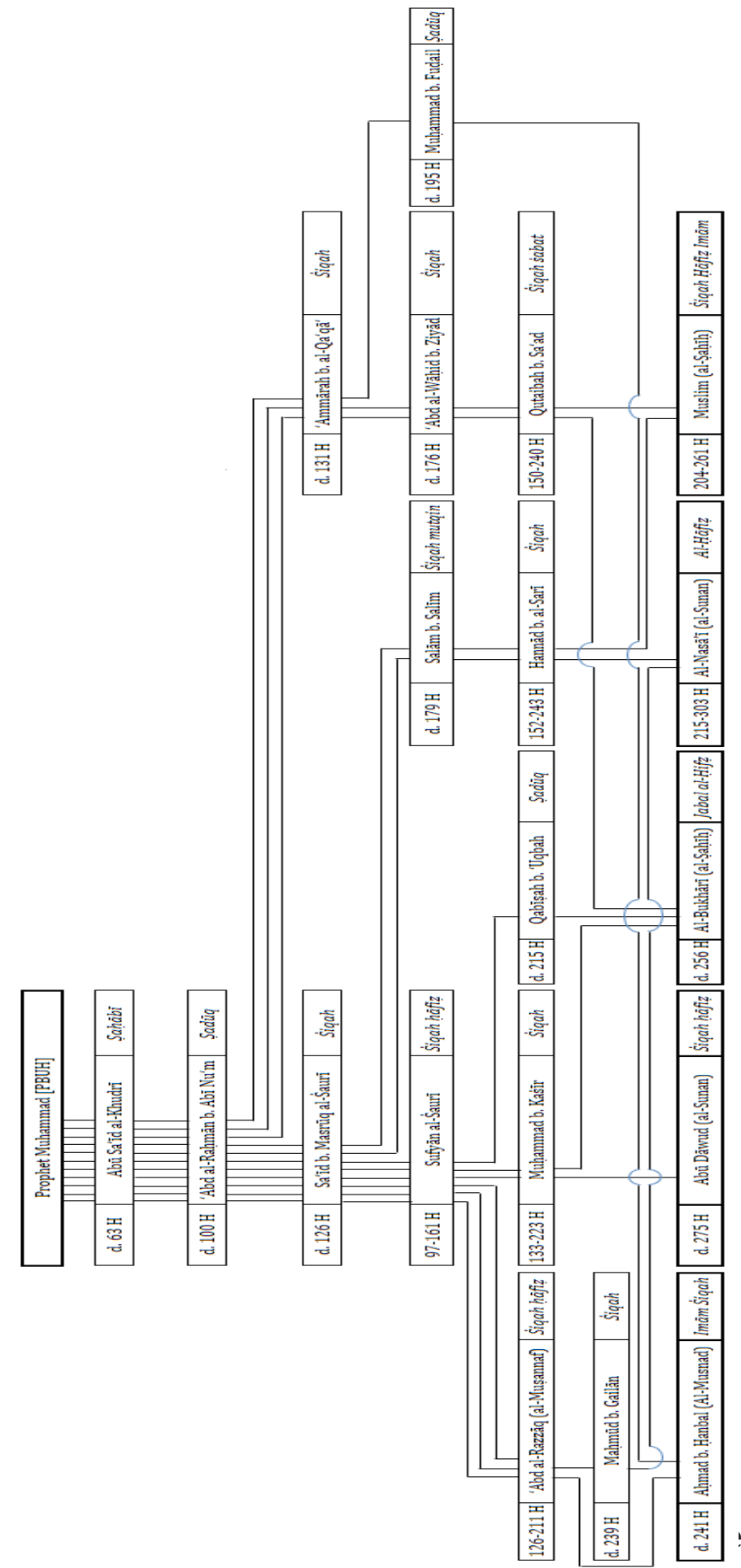


narrators in this Hadith isnād claimed siqah by the scholars of Hadith criticism through the jarh wa ta'dìl method. Also, the years of death among each isnād are not much different, so they are considered to have the opportunity to meet each other to receive the narrations of Hadith during their lifetime. However, based on figure 1 , three narrators tend to be in the seeming common link (collectors), namely 'Abd al-Raḥmān bin Nu'm and two of his students, Sa'īd bin Masrūq and 'Umārah bin al-Qa'qā'. Therefore, these three Hadith began to spread widely around the first half of the third century of Hijriah.

'Abd al-Raḥmān bin Abī Nu'm also known by Abū al-Hakam who was domiciled in Kufah, died around 100 Hijriah during the reign of 'Abd al-Malik bin Marwān (AlBusțī, 1991). He was known as a zuhud and an expert in worship. He was also known to be diligent in fasting, and even Al-Mugīrah revealed that Abū al-Hakam had fasted for 15 consecutive days until he looked sick (Al-Aṣbahānī, 2004). Al-Nasā'ī and Ibn Hibbān claim him as siiqah, while Ibn Ma'īn claims him as ḍa'îf (Al-Żahabī, 1963, vol. 2, p. 595). He also narrated Hadith from several companions such as Abū Sa'īd al-Khudrī and Abū Hurairah. However, not many Hadiths can be found in the collection he narrated (Al-Żahabī, 1986, vol. 5, p. 62). Sa'īd bin Masrūq and 'Umārah bin al-Qa'qā' are listed as two of his disciples. Sa'īd bin Masrūq died around the year 126 Hijrah or during the reign of 'Abdullah bin 'Umar bin 'Abd al-'Azīz in Iraq (AlBagdādī, 1968, vol. 6, p. 327). He also lived in Kufah, which was claimed siqah by the scholars of Hadith (Al-Żahabī, 2003, vol. 3, p. 423). Likewise, 'Umārah bin al-Qa'qā'died around 144 Hijriah (Al-Bustī, 1991, p. 265). He is also domiciled in Kufah which is also agreed to be qualified 
siqah. 'Abd al-Wāhid bin Ziyād and Jarīr bin Fuḍail narrated from him the traditions about Prayers, Testaments, and others (Al-Kalābażī, 1986). In addition, he is also recorded as narrating Hadith with Sufyān al-Ṡaurī. Ibn al-Madīnī revealed that he narrated about 30 narration recorded from him (Al-Mizzī, 1980, vol. 21, p. 263).

Based on the review of the biographical history of the three isnād lines, there are no irregularities in the calendar and assessment of the jarh and ta'dìl among the three. They can be sure to transmit the Hadith history to one another. When referring to Juynboll's (2008) Common Link theory, the dating of the transmission of this Hadith is considered not problematic. However, investigating the transmission of isnād alone is not sufficient when referring to the Isnād-cum-Matn Motzki (2005) theory because it is also important to examine the authenticity of the matn of Hadith. The aim is to trace the existence of text (syāż), both addition (idrāj) and subtraction (nuqșān) contained in it. Therefore, the following discussion is projected to describe the analysis of the Hadith matn.

\section{Matn Analysis}

Although the Hadith is narrated from the same sahābah and tābi'în, there are two different versions of the text. The eight historical pathways contain redaction as narrated by al-Bukhārī, while the other three narrative lines have additional phrases as shown in the following Hadith:

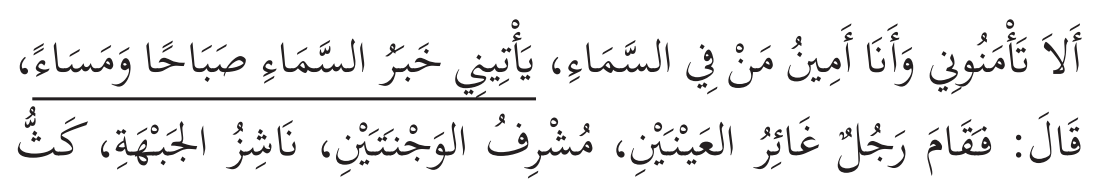




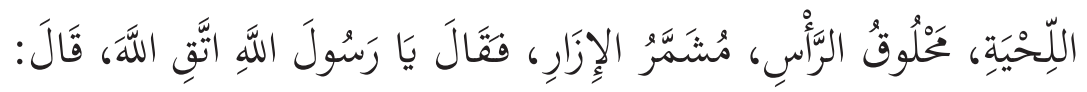

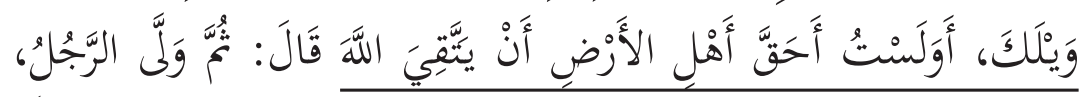

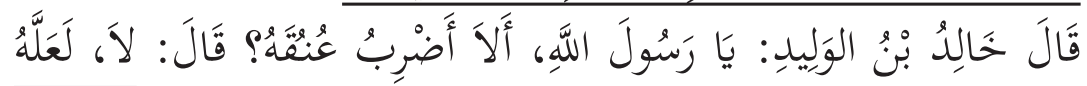

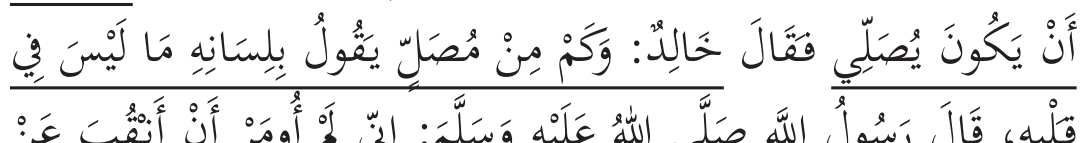

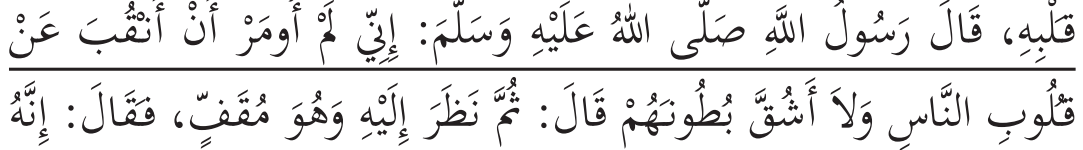

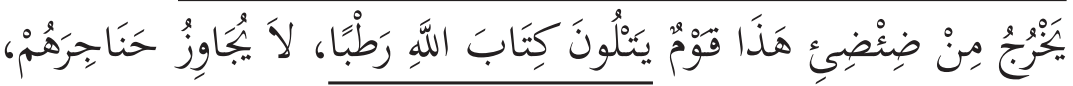

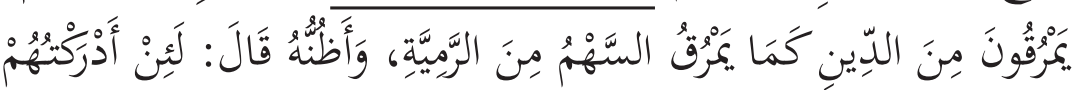

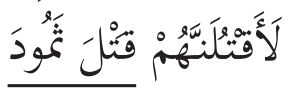

The underlined clause is not found in any other Hadith version. This version is found in a three-line narrative that comes from 'Umārah bin al-Qa'qā', while another version of the eight narrations comes from Sa'îd bin Masrūq. There are three significant differences related to the Hadith between the version of Sa'îd bin Masrūq and the version of 'Umārah bin al-Qa'qā'. First, the version of 'Umārah bin al-Qa'qā' contains the phrase "lā, la 'allahū an yakūna yușallī" which is not included in the version of Sa'îd bin Masrūq's narrative. Second, the Sa'īd bin Masrūq version contains the phrase "yaqtulūn ahl al-Isläm wa yatrukūn ahl al-awsiān" which is not found in the narrated version of 'Umārah bin al-Qa'qā'Third, the version of Sa'īd bin Masrūq which contains the phrase "Ia'aqtulannahum qatl 'âd", while the 'Umārah bin al-Qa'qā' version uses the phrase "qatl samüd". 
However, it seems difficult to prove the occurrence of idrāj (insertion) or nuqșān (reduction) between the two versions of Sa'īd bin Masrūq's narrative and the version of 'Umārah bin al-Qa'qā', because both are recorded in Șạhịain (book al-Bukhāri and Muslim). Therefore, the phrases of "yaqtulūn ahl al-Islām wa yatrukūn ahl al-awsīan" and "la'aqtulannahum qatl àd" or "la'aqtulannahum qatl șamūd" are significant and substantive phrase in explaining the criteria intended by the Prophet. The phrase of "la'aqtulannahum qatl 'âd" or "la'aqtulannahum qatl samūd" at the end of the entire Hadithsuggests the regressiveness of the Prophet, so that the phrase of "yaqtulūn ahl al-Islām wa yatrukūn ahl alawśān" is a logical reason for the Prophet's statement. Even the promise of great rewards on the Day of Judgment for those who managed to kill him (Abū Dāwud, 2009, vol. 4, p. 244; Al-Bukhārī, 1993, vol. 4, p. 200; Al-Nasā'ī, 1986, vol. 7, p. 119) also a proper legitimacy. This is reinforced by a narration of Abū Sa'īd which states that they are the worst beings (syarr al-khalq wa al-khalīqah) because their beautiful speech is not in tune with their bad behavior (yuhsinūn al-qīla wa yusīunna al -fi'la), so that their presence is prone to causing conflicts that have an impact on the division of the people (Abū Dāwud, 2009, vol. 4, p. 243). The order to kill is a logical implication for their existence, which is potentially dangerous for Muslims. It is in line with the statement of the Prophet in other narrations that their appearance was related to divisions and conflicts among the people (Al-Naisāburi, 1990, vol. 2, p. 160-161).

Some other information also shows that the characteristics mentioned in the Hadith reports are 
associated with the Khawärij group. One of them is the narration of 'Alī bin Abī Țālib when discussing the characteristics of the Khawārij group. The characteristics in the history add information about physical characteristics such as the size of his body, which tends to be short, and lumps and white hairs on his arms (Abū Dāwud, 2009, vol. 4, p. 245). The Hadith also adds to the phrase of the oath uttered by 'Alī bin Abī Tâlib three times to confirm the legitimacy that these characteristics he heard directly from the Prophet. Likewise, another narration of 'Alī bin Abī Țālib is found which is similar to that narration. However, this history does not show any specific explanation regarding the micro-historical context that underlies it. However, the other version of the Hadith added two criteria, namely "ḥudaśā 'al-asnān sufahā al-aḥlām" or being young, but having intellectual limitations, and "yaqūlūna min qauli khair al-bariyyah" or having capable rhetorical communication skills. The information in this narrative is in line with the narrations conveyed by other narrations through the route 'Abdullah bin Mas'ūd (Ibn Abī Syaibah, 1409, vol. 7, p. 553; Ibn Mājah, 2009, vol. 1, p. 59).

On various occasions, the Hadith narrations were also conveyed by other Companions when responding to events or questions related to the criteria mentioned in this narration. For example, the history of Abū Sa'īd alKhudrī who conveyed the words of the Prophet when asked about the al-Harūriyyah group, which was called a sect of the Khawārij group (Al-Bukhārī, 1422, vol. 9, p. 16; Al-Ḥajjāj 1991, vol. 2, p. 163; Al-Ṣan'ānī, 1403, vol. 10, p. 146; Hanbal 2001, vol. 25, p. 351; Ibn Abī Syaibah 1409, vol. 7, p. 560; Ibn Mājah 2009, vol. 1, p. $60)$. The Hadith version that mentions this sect contains 
additional information, namely "yata'abbadūn" or people who maximally perform ritual worship (Ibn Abī Syaibah, 1409, vol. 7, p. 557; Ibn Mājah, 2009, vol. 1, p. 60) and "yata'ammaqūna fì al-dīn" or people who are always diligent in their religious practice (Hanbal, 2001, vol. 17, p. 393). Therefore, the text of this Hadith can be considered masyhūr (famous) or mutawātir maknawī (narrated communally based on it meaning) among Muslims in the $7^{\text {th }}$ century Hijriah because it was narrated from many narrators with similar substance meanings.

\section{F. The Characteristics of Good-Looking}

From the overall hHadith text, it can be hermeneutically mapped into five characteristics as an indicator of the relationship between ritual piety and religious violence. This research calls it good-looking. The characteristics are mapped in the illustration table 1.

Table 1: Characteristics of good-looking in the text of Hadith

\begin{tabular}{|c|c|c|}
\hline Nu. & Characteristics & Text of Hadith \\
\hline 1 & Religious symbolism & $\begin{array}{l}\text { "gā'ir al-'ainaini", "mahhlūq al-ra'si" } \\
\text { "musyrifal-wajnataini", "nāti'al-jabīn", } \\
\text { "nāsyiz al-jabhah", "kaśś al-lihya", and } \\
\text { "musyammar al-izāri" (Abū Dāwud } \\
\text { 2009, vol. 7, p. 142; Al-Bukhārī 1993, } \\
\text { vol. 3, p. 1219, vol. 4, p. 1581, vol. 6, } \\
\text { p. 2702; Al-Hajjāj 1955, vol. 2, p. 741, } \\
\text { 742; Al-Nasā'ī 1986, vol. 5, p. 87, vol. } \\
\text { 7, p. 118) }\end{array}$ \\
\hline 2 & $\begin{array}{l}\text { Absolute truth } \\
\text { monopoly }\end{array}$ & $\begin{array}{l}\text { "ittaqi-llāh yā Muhammad" and "i'dil } \\
\text { yā Muhamamad" or "innaka lam ta'dil" } \\
\text { (Hanbal 2001, vol. 23, p. 123; Ibn } \\
\text { Mājah 2009, vol. 1, p. 61) }\end{array}$ \\
\hline
\end{tabular}




\begin{tabular}{|c|c|c|}
\hline 3 & $\begin{array}{l}\text { Obedient to carry out } \\
\text { rituals, without a solid } \\
\text { religious knowledge } \\
\text { base }\end{array}$ & $\begin{array}{l}\text { “yaqra'ūna al-Qur'ān lā yujāwizu } \\
\text { hanājirahum" (Abū Dāwud 2009, vol. } \\
\text { 7, p. 142; Al-Bukhārī 1993, vol. 3, p. } \\
\text { 1219, vol. 6, p. 2702; Al-Nasā'i 1986, } \\
\text { vol. 5, p. 87, vol. 7, p. 118) }\end{array}$ \\
\hline 4 & $\begin{array}{l}\text { Easy to change the } \\
\text { belief }\end{array}$ & $\begin{array}{l}\text { "yamruqūn min al-dīn kamā yamruq } \\
\text { al-sahm min al-ramiyyah" (Abū } \\
\text { Dāwud 2009, vol. 7, p. 145; Al- } \\
\text { Bukhārī 1993, vol. 3, p. 1321, vol. 4, p. } \\
\text { 1581, vol. 4, p. 1927; Al-Hajjāj 1955, } \\
\text { vol. 2, p. 740, 741, 742, 744, 746, 747, } \\
\text { 748; Al-Nasā'ī 1986, vol. 5, p. 87, vol. } \\
\text { 7, p. 119; Al-Tirmiżì 1975, vol. 4, p. } \\
\text { 481; Hanbal 2001, vol. 2, p. 95, 114, } \\
\text { 329, 411, 431, 453, 471) }\end{array}$ \\
\hline 5 & $\begin{array}{l}\text { Tend to take } \\
\text { repressive actions }\end{array}$ & $\begin{array}{l}\text { “yaqtulūn ahl al-Islām wa yad'ūna ahl } \\
\text { al-awsiān" (Abū Dāwud 2009, vol.7, p. } \\
\text { 142; Al-Bukhārī 1993, vol. 3, p. 1219, } \\
\text { vol. 6, p. 2702; Al-Hajjāj 1955, vol. 2, } \\
\text { p. 741; Al-Nasā'ī 1986, vol. 5, p. 87) }\end{array}$ \\
\hline
\end{tabular}

The first character embodies physical appearance as a symbol of ritual piety, as shown in the Hadith text, which mentions the characteristics of people who insult the Prophet. Friends described the person as having sunken eyes ( $g a \bar{a}$ 'ir al-'ainaini), prominent temples (musyrif al-wajnataini), thick beard (kaśs al-lihyah), hair shaved so that his head was bald (mahlūq al-ra'si), and his clothes lifted above his ankles (musyammar al-izāri). Another narration describes the way they dressed clean and tidy (śaubāni abyadāni) and had a prostration mark on their forehead (baina 'ainaihi aśar alsujūd) (Al-'Ainī, 2001, vol. 18, p. 11; Ibn Al-Mulqin 2008, vol. 21, p. 521).

Second, it is easy to claim the mistakes of others using negative justifications, even the policy of the Prophet Muhammad as the messenger of Allah was also protested, 
as seen in the phrase "ittaqi-llāh yā Muhammad" or "yā Muhammad mā 'adalta". This character is reinforced by the spirit of the claim of justification which is not accompanied by adequate intellectual capacity, as confirmed by another narration sourced from 'Alī bin Abī Tạalib which describes one of the characters predicted by the Prophet as "hudasia' al-asnān, sufahā al-aḥlām” (Al-Bukhārī 1422, vol. 4, p. 200). Such low intellectual capacity causes them to be unable to properly understand the philosophical meaning and purpose of the Prophet's policy, in this case, his policy not to share the spoils of war evenly. This is what underlies their accusations and insults against the Messenger of Allah, which they claim to be unfair. Therefore, their claim to truth has shifted from what it should be (Al-Qasțalānī 1323, vol. 6, p. 59). The scholars even call their phrase "kalimat haqq urīdu bihā bāțil" (an expression that is cursory true but its true purpose is evil) (Al-Nawawī 1392, vol. 7, p. 173).

Third, ritual piety is simply symbolic, which has no implications for the practice of religious morality, as seen in the phrase "lā yujāwizu hanājirahum". The Prophet in more detail mentioned the characters "yaqra'ūna al-Qur'ān" and "tuhqirūna șalātakum ma'ā șalātihim, wa șiyāmakum ma'a șiyāmihim, wa 'amalakum ma'a 'amalihim", namely reading fluency and enthusiasm for worship that surpasses the average person so that other Muslims feel less good about the group's worship. Apart from rituals, they also have high rhetorical abilities, and even their speech is dominated by revelation narratives as depicted in the Prophet's words "yaqūlūna min qauli khair al-bariyyah" and "yatakallamūna bi kalimat al-haqq". However, Rasulullah claims "yuhsinūna al-qaula wa yusī'ūna al-fi' la", that their rhetorical abilities are not in line with their morals. That is why some scholars consider that behind the privileges of those 
who are obedient in carrying out the ritual, they are suspected of having minimal or below average intellectual abilities (sufah $\bar{a}$ al-aḥlām) (Al-Qasțalānī, 1323, vol. 7, p. 486). Therefore, their proficiency in reading the Qur'an, as well as their persistence in carrying out ritual worship, is not directly proportional to their social behaviour in their religious life.

Al-Zarqanī also revealed that one of the factors of heresy here is their fluent reading of the Qur'an, but it is not accompanied by understanding and appreciation, even tends to reduce the meaning of the Qur'an (Al-Zarqānī, 2003, vol. 2, p. 19). Thus, the expression "lā yujāwizu hanājirahum" in the Hadith text does not mean that they only read the Qur'an without trying to interpret it. They do exactly that, but simultaneously, they reduce the meaning of the substance. The reduction in meaning they do is not because of kufr (heathen) background, but because of their stubbornness to open their insights into their knowledge. Al-Asybilī also claimed that it was suspected that it could be more dangerous than kufr itself (Al-Asybīlī, 1992, vol. 1, p. 404). Lāsyīn also stated that the ignorance mentioned in the text of the Hadith was considered more dangerous because it was covered by a pious, zuhud, solemn appearance and capable rhetorical abilities, but his behavior was not directly proportional to his words (Lāsyīn, 2002, vol. 4, p. 444).

Fourth, the inability to maintain faith, making it easy to change beliefs. It is shown in the phrase "yamruqun min al-dīn kamā yamruq al-sahm". Another Hadith also mentions "yakhrujūn min al-dīn" which confirms that the diction "yamruq" connotes the meaning of their departure from religion, even though at the same time they are still Muslim. It was emphasized by the Messenger of Allah by analogizing their diversity as a bow that released quickly and pierced its 
target but did not leave the slightest trace on the bow, animal flesh, or feathers. An expression is a form of metaphor or analogy which shows a sign that it is as if people who have these characteristics have a religion like a bow that is fired fast. It means that obedience to religious orders is their priority. However, just like a bow that has pierced an animal's body without leaving a trace or a drop of blood all over the bow, they can also leave religious orders from the base to the tip. At the beginning of the Hadith, this analogy is synchronous with the phrase stating that their Qur'an recitation is restricted to ritual or reading. In line, Al-Qastalanī revealed that they were fluent when reading the verses of the Qur'an, but did not make an impression on their hearts and behaviour (Al-Qasțalānī, 1323, vol. 7, p. 486). Similarly, the analogy expressed by al-Zarqānī is that their connection with religion is like a person who only eats and drinks for the benefit of his throat but does not benefit his body's health at all (Al-Zarqānī, 2003, vol. 2, p. 19).

The phrase "yamruqūna min al-dīn", which means leaving Islam, is used as an argument by some scholars such as Ibn al'Arabī to associate them as unbelievers (Al-Zarqānī, 2003, vol. 2, p. 19). It is different with al-Nawawī and al-Khațtābī who are reluctant to position them as infidels because according to them, the characteristics described by the Messenger of Allah are not included in the character of unbelievers and hypocrites (Al-Qasțalānī, 1323, vol. 7, p. 486; Lāsyīn, 2002, vol. 4, p. 444). They are different from unbelievers because they are like people who believe and diligently worship, also different from hypocrites who are reluctant to make dhikr (remember Allah), while they are obedient and diligent in doing dhikr in the morning and evening. As for Al-Khațābī stated that they are like believers but "blind and deaf", so it is easy for them to be misled (Al-Qasțalānī, 1323, vol. 7, p. 486). 
Fifth, committing acts of violence against fellow Muslims, as shown in the phrase "yaqtulun ahl al-Islām wa yatrukūn ahl al-aws்ān". Their actions were claimed by the Messenger of Allah as treasonous acts that could cause chaos and division of the ummah, as stated in the phrase "yakhrujūna 'alā hìni furqatin min al-nās" and "sayakūnu fi ummatī ikhtilāf wa furqah". In response, the scholars considered the punishment they deserved was death. It appears in the Hadith text through the narrations of Abù Sa'îd, Ibn Mas'ūd, and 'Alī bin Abī Taalib. The order is claimed to be an order which is obligatory through the oath sign used by 'Alī bin Abī Țālib when conveying this narration to his student. Al-Nawawì also confirmed this claim; he considered that the scholars had agreed upon the Hadith narrative as the basis for the obligation to execute the Khawārij people and similar mess makers. In line , al-Qāḍi also emphasized that basically, it is not only the Khawārij group that must be put to death but also people who have the character of making heresy and confusion. Actually, he limited it specifically to the behavior of people who opposed the leader, violated congregational agreements, and damaged public facilities (Al-Uramī, 2009, vol. 12, p. 275).

The five good-looking characteristics extracted from the text of the Hadith, when linked to the indicators of religious violence formulated by Kimbal, can be found in some identical characteristics. It is illustrated in the visualization as in Table 2:

Table 2: Characteristic Relation between Good-Looking and Religious Violence

\begin{tabular}{ll}
\hline \multicolumn{1}{c}{ Good-looking } & \multicolumn{1}{c}{ Religious Violence } \\
\hline Religious symbolism & Absolute truth clime \\
\hline Absolute truth monopoly & Blind obedience \\
\hline $\begin{array}{l}\text { Obedient to carry out rituals without a solid } \\
\text { religious knowledge base. }\end{array}$ & $\begin{array}{l}\text { Establishing the ideal } \\
\text { time }\end{array}$ \\
\hline Easy to change the belief & Justifies any means \\
\hline Tend to take repressive actions & Declaring holy war \\
\hline
\end{tabular}


The two groups of characteristics appear identical, even though each group has a different characteristic. Religious symbolism does not appear to be found in Kimball's characteristics, and establishing the ideal time is not found in the characteristics mentioned in the Hadith. However, the two groups of characteristics can complement each other to identify the characteristics of religious adherents who adhere to ritual or spiritual teachings but are prone to commit acts of violence in religion.

\section{G. Discussion: Responding to the Characteristics of Good- Looking}

The perfection of one's religiosity will not be realized if it is only armed with religious piety or spirituality without being equipped with moral values. Moreover, it tends to encourage the emergence of the religious violence practice. This morality can only be formed through an established scientific capital without limiting religious insight only to a theological perspective alone. When referring to the various good-looking characteristics illustrated in the Hadith history, it appears that the characteristics of the person mentioned in it are devoid of moral values. That is why the parameters of justice or truth he uses only considering aspects that are appeared normative or limited to ritual judgments alone. It is in line with Wahib's (2017) findings which perceive the Islamic ideological group Salafism tendency in Indonesia. The findings show that this group tends to impose their understanding to be applied by other Islamic groups. They carried out this action under the pretext of purifying Islamic teachings by transforming a dress style under the aesthetic characteristics of the Middle East (Arab State) and using Arabic as the primary language in Islam. Their purpose is to 
create intimacy among the members of their group. However, at the same time, they distance themselves from Muslims who are different from their ideology (Wahib 2017).

This good-looking characteristic can not only be found in the religious activities of traditional community groups but has also been distributed through the practice of religious mediation in virtual social media. The religious nuances displayed in it are more specifically directed at the contestation of symbols of ritual piety (Amir 2019). Such phenomena can be seen from the various posts of religious community groups or organizations in Indonesia that are increasingly spreading such expressions. Every day, users post posts, memes, videos, and images on social media to emphasize their position of ritual piety. At the same time, they either present scorn for other ideologies or openly condemn the thoughts and practices of Muslims that differ from them (Slama \& Barendregt, 2018). The emergence of this phenomenon cannot be separated from interpreting revelation texts that are understood in a simplified manner. Venkatraman (2007) revealed that extreme religious interpretations originate from the Islamic Revivalism movement group's reduction in interpretations of revelation texts. Through the term Jihad, they have legalized acts of religious violence that ostensibly originate from authoritative Islamic teachings (Venkatraman 2007). Faisal (2018) revealed that the reductionist act of interpretation caused such misinterpretation. Each religious group only debated the results of their interpretation at the level of surface meaning (literal meaning), but ignored the historical contextual aspect to obtain its significance.

A different response was shown by Sanjeev Kumar (2015), he argues that the discourse on terrorism is just a form of Western criticism of the Muslim world. They criticize 
Islam as a religion that tends to teach violence. Additionally, he claims that such views appear superficial and stand on flimsy grounds. They have disguised a grand strategy by using the war against terrorists, which is subtly aimed at Muslims. To justify attacking Islam, they created ambiguous terminology such as the words jihād, Dār al-Islam and Khiläfah, which are associated as part of the concept of terrorism (Sanjev Kumar, 2015). In response to this, this research responds by showing that the Hadith studied has explicitly acknowledged the existence of these extremist groups. However, it must be admitted that the determination of violence against certain religious groups cannot be justified because the attitude of violence depends on the individual characteristics of each member of the religious group. This redaction refers to personal objects, not to communal objects. It means that each member of a religious group contains individuals who have extremist characteristics, whether from groups of the left, right, or even moderate. Thus, the characteristics proposed in this study can act as parameters of violence in various ways without looking at specific religious groups. It is in line with al-Qā dī's affirmation that treason was not only born from the Khawārij group but could also arise from other different ideological groups (Al-Uramī, 2009, vol. 12, p. 275).

At the end section of the Hadith, there is an expression of the Prophet who criticizes people who have characteristics such as good-looking which is seen in the phrase "la-'in anā adraktuhum la -aktulannahum qatl 'Ād" ("If I should live up to their time' I will kill them as the people of 'Ad were killed"). This expression seems to show the impact of their movement, which is very dangerous because it can threaten the integrity of the people. However, this study does not recommend repressive measures to overcome them. This study is more in 
agreement with the recommendations of Syam et al., (2020) which reveal that utilizing violence to counter radicalism and terrorism is not appropriate or suitable with Indonesia's socio-cultural context. Historically, solving problems through acts of violence in Indonesia can only generate revenge and initiate new seeds of radicalism (Syam et al. 2020, p. 1-27). Thus, the ideal treatment is to proactively counter-narrative or dominate the narratives of moderate Islamic teachings, primarily through the interaction of virtual discussion spaces. Such narratives can be distributed through virtual social media services, given that people's religious enthusiasm tends referring to sources of religious teachings through virtual social media. However, it takes the right strategy to design effectively and measurably. Therefore, research on the counter-strategy of religious violence narratives through virtual social media is considerably recommended for further study in subsequent studies.

\section{H. Conclusion}

The relationship between ritual piety and the tendency of religious violence shown through the good-looking characteristics is not a new discourse in Islamic thought. This phenomenon has appeared since the $7^{\text {th }}$ century Hijriah or the prophetic era. Such narratives can be found in the Hadith narrations recorded in the authoritative Hadith literature such as Musannaf 'Abd Razzāk al-San'ānī, al-Kutub al-Tis'ah, and al-Mustadrak 'alā Sậihain. The narrations recorded in the Hadith literature are also predominantly at the level of șahịh, even masyhūr to mutawātir ma'nawī. Thus, the claim to a relationship between ritual piety and the potential for religious violence or good-looking is not entirely wrong, even though such characteristics cannot be generalized to certain 
religious groups. The characteristics of good-looking are individualistic, or each religious group may have members who share these characteristics. Identifying the five good-looking characteristics cannot be claimed partially or independently but applies as a whole. It means that it is not enough to use one characteristic to claim that someone has the characteristics of violence in religion, but that the characteristic is multifaceted. The tendency for each member of a religious community to develop these characteristics is induced by their variety which is free of religious moral standards. Morality comes from a broad religious perspective so that it does not merely judge the truth from a theological-normative point of view. Therefore, the proposed solution in this study to minimize the dangers of the good-looking religious phenomenon is to increase religious moderation narratives, primarily through virtual proselytizing on social media. It is because the dominance of Muslims is more intense in obtaining information on Islamic teachings through this media. However, this research has not yet reached the stage of formulating the right strategy for realizing this movement, thus, this study recommends further formulation to be followed up in subsequent studies.

\section{REFERENCE}

Abū Dāwud, S. bin al-A. al-S. (2009). Sunan abī dāwud (M. M. al-D. 'Abd Al-Ḥamīd (ed.)). al-Maktabah al-'Așriyah.

Achilov, D., \& Sen, S. (2017). Got political islam? Are politically moderate muslims really different from radicals? International Political Science Review, 38(5), 608-624. https://doi.org/https://doi. org/10.1177/0192512116641940 
Afsaruddin, A. (2008). Making the case for religious freedom within the islamic tradition. The Review of Faith \& International Affairs, 6(2), 57-60. https://doi.org/ https://doi.org/10.1080/15570274.2008.9523339

Afsaruddin, A. (2009). The hermeneutics of inter-faith relations: Retrieving moderation and pluralism as universal principles in qur'anic exegeses. Journal of Religious Ethics, 37(2), 331-354. https://doi.org/ https://doi.org/10.1111/j.1467-9795.2009.00389.x

Al-'Ainī, M. bin A. bin M. (2001). 'Umdat al-qārī syarḥ șaḥīh albukhārī. Dār al-Kutub al-'Ilmiyyah.

Al-Aṣbaḥān̄̄, I. bin M. bin al-F. (2004). Siyar al-salaf al-șāliḥinn. Dār al-Kutub al-'Ilmiyyah.

Al-Asybīlī, A. B. ibn al-'Arabī. (1992). Al-Qabs fì syarh muwatța' mālik (M. 'Abdullāh W. Karīm (ed.)). Dār al-Garb alIslāmī.

Al-Bagdādī, M. bin S. (1968). Al-țabaqāt al-kubrā (I. 'Abbās (ed.)). Dār Șādir.

Al-Bukhārī, M. bin I. (1993). Șaḥịh al-bukhārī (M. D. Al-Bigā (ed.); V). Dār Ibn Kaśīr, Dār al-Yamāmah.

Al-Bustī, M. bin Ḥibbān. (1991). Masyāhīr 'ulamā al-amṣār wa a lām fuqahā al-aqțār (M. 'Alī Ibrāhīm (ed.)). Dār alWafā.

Al-Ḥajjāj, M. bin. (1955). Șaḥīh muslim (M. F. 'Abd Al-Bāqī (ed.)). Maṭba'ah 'Īsā al-Bābī al-Ḥalbī.

Al-Kalābaż̀̄, A. bin M. (1986). Al-Hidāyah wa al-irsyād fì ma'rifah ahl al-siqah wa al-sadād ('Abdullah al-Laisī̄ (ed.)). Dār al-Ma'rifah. 
Al-Mizzī, Y. bin 'Abd al-R. (1980). Tahżìb al-kamāl fì asmā alrijāl (B. 'Awwād Ma'rūf (ed.)). Muassasah al-Risālah.

Al-Naisāburi, A. A. al-Ḥākim. (1990). Al-Mustadrak 'alā alșaḥịhain (M. 'Abd Al-Qādir (ed.)). Dār al-Kutub al'Ilmiyyah.

Al-Nasā'ī, A. 'Abd al-R. A. bin S. (1986). Sunan al-nasā'ī. Maktabah al-Mațbū'ah al-Islāmiyah.

Al-Nawawī, Y. bin S. (1392). al-Minhāj syarḥ șaḥịh muslim. Dar Ihyā' al-Turās al-'Arabī.

Al-Qasțalānī, A. bin M. bin A. B. (1323). Irsyād al-sārī li syarh șaḥịh al-bukhārī. al-Maṭba'ah al-Kubrā al-Amīriyyah.

Al-Ṣan'ānī, 'Abd al-Razzāq. (1403). al-Mușannaf (Ḥabīb alRaḥmān Al-A'ẓamī (ed.); II). al-Maktab al-Islāmī.

Al-Syaukānī, M. b. 'Abdullāh. (1993). Nail al-auțār. Dār alHadīs̀.

Al-Tirmiżì, M. bin I. (1975). Sunan al-tirmiżī (I. Ațwah (ed.)). Maktabah al-Babiy al-Halabi.

Al-Uramī, M. al-A. bin 'Abdillāh. (2009). Al-Kaukab al-wahhāj wa al-rauḍ al-bahhāj fĩ syarh șahīḥ muslim bin al-ḥajjāj. Dār al-Minhāj.

Al-Żahabī, S. al-D. (1963). Mīzān al-I'tidāl fì Naqd al-rijāl. Dār al-Ma'rifah.

Al-Żahabī, S. al-D. (1986). Siyar A'lām al-nubalā. Muassasah alRisālah.

Al-Żahabī, S. al-D. (2003). Tārīkh al-islām wa wafayāt almasyāhīr wa al-a'lām (B. 'Awwād Ma'rūf (ed.)). Dār alGarb al-Islāmī. 
Al-Zarqānī, M. bin 'Abd al-B. bin Y. (2003). Syarḥ al-zarqānī 'ala muwatța al-imām mālik (Țāhā 'Abd al-Raūf Sa'ad (ed.)). Maktabah al-Śaqāfah al-Dīniyyah.

Amir, A. M. (2019). The identity of piety in the digital age (Study of the use of religious symbols in social media). Islamic Studies Journal for Social Transformation, 3(1), 37-55. https://doi.org/https://doi.org/10.28918/ isjoust.v3i1.1947

Ansor, M. (2016). Post-islamism and the remaking of islamic public sphere in post-reform indonesia. Studia Islamika, 23(3), 471-515. https://doi.org/http://doi. org/10.15408/sdi.v23i3.2412

Asih, R. W. (2020). Disebut tak pantas jadi menag, begini jawaban fachrul razi saat ditanya soal "radikal-good looking." Tribunnews.Com.

Baumsteiger, R., Chenneville, T., \& McGuire, J. F. (2013). The roles of religiosity and spirituality in moral reasoning. Ethics \& Behavior, 23(4), 266-277. https://doi.org/ https://doi.org/10.1080/10508422.2013.782814

Cohen, A. B., \& Johnson, K. A. (2017). The relation between religion and well-being. Applied Research in Quality of Life, 12(3), 533-547. https://doi.org/https://doi. org/10.1007/s11482-016-9475-6

Duderija, A. (2007). Islamic groups and their world-views and identities: neo-traditional salafis and progressive muslims. Arab Law Quarterly, 21(4), 341-363. https:// doi.org/10.1163/026805507X247554

Faisal, bin A. S. (2018). The misinterpretation of hadith texts by extremist groups to justify their terrorist acts: 
an analysis. Al-Bayan: Journal of Qur'an and Hadith Studies, 16(2), 163-186. https://doi.org/https://doi. org/10.1163/22321969-12340060

Ghosh, R., Chan, W. A., Manuel, A., \& Dilimulati, M. (2017). Can education counter violent religious extremism? Canadian Foreign Policy Journal, 23(2), 117-133. https://doi.org/https://doi.org/10.1080/11926422.2 016.1165713

Hanbal, A. A. A. bin M. (2001). Musnad ahmad (S. Al-Arnaut \& A. Mursyid (eds.)). Muassasah al-Risālah.

Henningsgaard, J. M., \& Arnau, R. C. (2008). Relationships between religiosity, spirituality, and personality: a multivariate analysis. Personality and Individual Differences, 45(8), 703-708. https://doi.org/https:// doi.org/10.1016/j.paid.2008.07.004

Hogg, M. A., Adelman, J. R., \& Blagg, R. D. (2010). Religion in the face of uncertainty: an uncertainty-identity theory account of religiousness. Personality and Social Psychology Review, 14(1), 72-83. https://doi.org/ https://doi.org/10.1177/1088868309349692

Ibn Abī Syaibah, A. B. (1409). Al-Muṣannaf fi al-aḥādīs wa al$\bar{a} \dot{s} \bar{a} r($ K. Y. Al-Ḥut (ed.)). Maktabah al-Rusyd.

Ibn Al-Mulqin, S. al-D. 'Umar bin 'Alī bin A. (2008). Al-tauḍīh li syarḥ al-jāmi' al-ṣaḥịh (D. al-F. li al-B. al-'Ilmī wa T. AlTurās (ed.)). Dār al-Nawādir.

Ibn Mājah, M. bin Y. al-Q. (2009). Sunan ibn mājah ('Ābd al-Lațîf Hirzullah Syu'aib al-Arnaūt, 'Ādil Mursyid, Muhammad Kāmil (ed.)). Dār al-Risālah al-'Ālamiyah. 
Juynboll, G. H. A. (2008). Muslim tradition: studies in chronology, provenance and authorship of early hadith. Cambridge University Press.

Kimball, C. (2002). When religion becomes evil: five warning signs (Revised an). Harper-Collins Publishers.

Koenig, H. G., McCullough, M., \& Larson, D. B. (2000). Handbook of religion and health. Oxford University Press.

Kumar HM, S. (2015). Responding to western critiques of the muslim world: Deconstructing the cliche of islamophobia and the genealogies of islamic extremism. British Journal of Middle Eastern Studies, 42(4), 579598. https://doi.org/https://doi.org/10.1080/135301 94.2015.1037247

Kumar HM, S. (2018). How violence is islamized: an analysis of the western rhetoric on salafi movement and terrorism. International Studies, 55(1), 22-40. https://doi.org/ https://doi.org/10.1177/0020881718761768

Larsen, K. M., \& Rinkel, M. (2016). What does religion and spirituality mean to a racially diverse group of social work practitioners? Journal of Religion \& Spirituality in Social Work: Social Thought, 35(3), 200-221. https:// doi.org/https://doi.org/10.1080/15426432.2016.118 5990

Lāsyīn, M. S. (2002). Fatḥ al-mun'im syarh șaḥịh muslim. Dār al-Masyrūq.

Motzki, H. (2005). Dating muslim traditions: A Survey. Arabica, 52(2), 204-253. http://www.jstor.org/stable/4057795

Osman-Gani, Aa. M., Hashim, J., \& Ismail, Y. (2013). Establishing linkages between religiosity and spirituality on 
employee performance. Employee Relations, 35(4), 360376. https://doi.org/https://doi.org/10.1108/ER-042012-0030

Rijal, S. (2020). Following arab saints: Urban muslim youth and traditional piety in indonesia." (2020): 1-24. Indonesia and the Malay World, 48(141), 1-24. https:// doi.org/https://doi.org/10.1080/13639811.2020.172 9540

Slama, M., \& Barendregt, B. (2018). Introduction: Online publics in muslim southeast asia: in between religious politics and popular pious practices. Asiascape: Digital Asia, 5(1-2), 3-31. https://doi.org/https://doi. org/10.1163/22142312-12340090

Sulaemang, L., Hadi, N., \& Amir, A. M. (2019). Rekonsiliasi antara islam dan local wisdom dalam kontekstualisasi hadith tentang larangan tashabbuh. Islamica: Jurnal Studi Keislaman, Vol. 13(12), 275-302.

Syam, F., Mangunjaya, F. M., Rahmanillah, A. R., \& Nurhadi, R. (2020). Narrative and the politics of identity: patterns of the spread and acceptance of radicalism and terrorism in indonesia. Religions, 11(6), 1-27. https://doi.org/ https://doi.org/10.3390/rel11060290

Tabti, S. (2019). The Charisma of Script: The quran and the hadith in neo-salafi online community. Journal of Religion in Europe, 12(2), 191-216. https://doi.org/ https://doi.org/10.1163/18748929-01202005

Venkatraman, A. (2007). Religious basis for islamic terrorism: the quran and its interpretations. Studies in Conflict \& Terrorism, 30(3), 229-248. https://doi.org/https://doi. org/10.1080/10576100600781612 
Wahib, A. B. (2017). Being pious among indonesian salafists. AlJami'ah: Journal of Islamic Studies, 55(1), 1-26. https:// doi.org/https://doi.org/10.14421/ajis.2017.551.1-26

Wibisono, S., Louis, W. R., \& Jetten, J. (2019). A Multidimensional analysis of religious extremism." 10 (2019): 2560. Frontiers in Psychology, 10(2560), 1-12. https:// doi.org/https://doi.org/10.3389/fpsyg.2019.02560

Wiktorowicz, Q. (2005). A genealogy of radical Islam. Studies in Conflict and Terrorism, 28(2), 75-97. https://doi. org/10.1080/10576100590905057 